\section{De novo adventitious root formations in mini-cuttings of Azadirachta indica in response to different rooting media and auxin treatments}

\author{
Ashok Gehlot $^{(1)}$, Rajesh Kumar Gupta ${ }^{(1)}$, Inder Dev Arya ${ }^{(1)}$, Sarita \\ Arya $^{(1)}$, Atul Tripathi ${ }^{(2)}$
}

Neem (Azadirachta indica A. Juss) is a multipurpose Indian tree important to local economy. Conservation of the genetic resources of neem is essential for the adaptability of this tree species to projected climate change impacts. Here, the effect of type and concentration of auxins in different rooting media on adventitious root formation (ARF) in mini-cuttings of Azadirachta indica is depicted. Three different rooting media (i.e., sand, vermiculite and soil) were used, and the experiment was established using three types of auxin (IBA, IAA and NAA) and 6 concentration treatment combinations $(100,250,500,750$, 1000 and $1500 \mathrm{mg} \mathrm{l}^{-1}$ ), in a complete randomized block design (CRBD). Significant effects of different auxin types, concentration treatments and rooting media on adventitious root formation of neem mini-cuttings were observed. Mini-cuttings were assessed for rooting percentage, number of roots, root length and number of leaves. IBA resulted in higher rooting percentage $(90 \%)$, number of roots $(149.56)$, root length $(14.83 \mathrm{~cm})$ and number of leaves per rooted mini-cuttings $(12.78)$, when growing in sand. The determination of proper rooting protocols and the use of mini-cuttings were proved important for improving mass propagation of $A$. indica.

Keywords: Mini-cuttings, Adventitious Root Formation (ARF), Azadirachta Indica, Auxin

\section{Introduction}

Azadirachta indica A. Juss, a member of Meliaceae family commonly known as neem, is a multipurpose evergreen tropical tree. It has been recognized as a versatile tree agroforestry purposes. Neem contains potent biodegradable and economically safe bio-pesticide compounds, such as azadirachtin (Purohit \& Dave 1996). When considered together, the various uses of neem can be very attractive to rural people that can easily get economic benefits through production of seeds and leaves within a short period of time.

Vegetative propagation (Parthiban et al.
1999) and breeding strategies for multipurpose traits including timber and non-timber products (Kundu \& Luukkanen 2003) are desirable for this species. However, when propagated through cuttings, neem shows difficult rooting. Goel \& Behl (2004) suggested the use of juvenile top cuttings for rooting induction in hard wood species such as neem, because physiologically mature tissues have lower rooting potential, take a long time to initiate roots and develop fewer roots.

Factors that influence the successful rooting of cuttings are reported by Garner \& Chaudri (1976) and Hartman et al. (1990):

$\square$ (1) Forest Genetics and Tree Breeding Division, Arid Forest Research Institute, Jodhpur 342001, Rajasthan (India); (2) Regional Pesticides Testing Laboratory, Department of Agriculture and Co-operation, Chandigarh (India)

@ Ashok Gehlot (agbios843@gmail.com)

Received: Nov 28, 2013 - Final Acceptance: Nov 13, 2014

Citation: Gehlot A, Gupta RK, Arya ID, Arya S, Tripathi A, 2014. De novo adventitious root formations in mini-cuttings of Azadirachta indica in response to different rooting media and auxin treatments. iForest 8: 558-564 [online 2014-12-09] URL: http://www.sisef.it/

iforest/contents/?id=ifor1189-007

Communicated by: Gianfranco Minotta

age of mother plant, season of cutting, type and height of cutting, presence or absence vegetative buds, number of leaves on the cutting, water content of stock plant and cutting. In addition, the formation of adventitious roots is a process induced and regulated by environmental and endogenous factors such as temperature, light, hormones (especially auxins), sugars, mineral salts and other molecules (Woodward \& Bartel 2005).

Auxin is one of the major endogenous hormones involved in the process of adventitious rooting (Wiesman et al. 1988). Physiological stages of rooting are correlated with changes in endogenous auxin concentrations (Heloir et al. 1996). Moreover, the use of exogenous plant growth regulators (PGRs) plays a vital role in influencing the sprouting and rooting of stem cuttings. The widely used sources of growth hormones for cuttings rooting are IBA (Indole-3-butyric acid), NAA ( $\alpha$-naphthalene acetic acid), and IAA (Indole-3-Acetic Acid) and commercialized root promoters (root-growing powders - Wiesman et al. 1988, Hartmann et al. 2007).

Use of mini-cuttings for propagation of different perennial plant species emerged as a popular technique recently (Titon et al. 2006) and has been proven to be effective and reliable for mass propagation of desired plants. Mini-cuttings allow genetic characteristics to be maintained (Stape et al. 2001, Wendling \& Xavier 2005, Schwambach et al. 2008, Wendling et al. 2010, Majada et al. 2011). The adventitious root ability in mini-cuttings has been extensively tested in Eucalyptus cloeziana (Almeida et al. 2007), $E$. benthamii Maiden \& Cambage $\times E$. dunnii Maiden (Brondani et al. 2008), E. globulus $\times$ E. maidennii (Schwambach et al. 2008 ) clones of $E$. benthamii and $E$. dunnii (Brondani et al. 2010a), E. benthamii (Brondani et al. 2010b) and Pinus pinaster (Majada et al. 2011) with positive results.

The de novo rooting is the most common form of rooting from cuttings. In the de novo Adventitious Root Formation (ARF), a new area of meristematic tissue is formed among the parenchyma cells at the anti-clinal division in the phloem ray parenchyma. The formation of adventitious roots is an essential step in vegetative propagation (Lovell \& White 1986). Adventitious roots can arise naturally from stem tissue under stressful environmental conditions, or may be induced by mechanical damage or following tissue culture regeneration of shoots $(\mathrm{Li}$ et al. 2009).

The present study was aimed to develop a cost-effective novel approach for clonal propagation of Azadirachta indica. We took advantage of controlled nursery conditions to apply ARF techniques for rapid and uniform production of high quality stocks 
Tab. 1 - Analysis of variance for the effect of auxins (IBA, IAA and NAA), their concentration and media on rooting percentage, number of root, root length $(\mathrm{cm})$ and number of leaves of $A$. indica mini-cuttings. (df): degrees of freedom.

\begin{tabular}{|c|c|c|c|c|c|c|c|c|c|}
\hline \multirow{2}{*}{$\begin{array}{l}\text { Source of } \\
\text { Variance }\end{array}$} & \multirow[t]{2}{*}{ df } & \multicolumn{2}{|c|}{ Rooting \% } & \multicolumn{2}{|c|}{$\begin{array}{c}\text { Number of } \\
\text { roots }\end{array}$} & \multicolumn{2}{|c|}{ Root length } & \multicolumn{2}{|c|}{$\begin{array}{c}\text { Number of } \\
\text { leaves }\end{array}$} \\
\hline & & $\mathbf{F}$ & $\mathbf{P}$ & $\mathbf{F}$ & $\mathbf{P}$ & $\mathbf{F}$ & $\mathbf{P}$ & $\mathbf{F}$ & $\mathbf{P}$ \\
\hline Auxin & 2 & 19.71 & 0.00 & 66.27 & 0.00 & 1.01 & 0.36 & 20.31 & 0.00 \\
\hline Media & 2 & 52.99 & 0.00 & 47.15 & 0.00 & 77.89 & 0.00 & 158.69 & 0.00 \\
\hline Concentration & 5 & 6.21 & 0.00 & 42.35 & 0.00 & 25.22 & 0.00 & 74.93 & 0.00 \\
\hline Auxin $\times$ Media & 4 & 1.48 & 0.20 & 9.45 & 0.00 & 0.03 & 0.99 & 36.39 & 0.00 \\
\hline Auxin $\times$ Concentration & 10 & 2.99 & 0.00 & 17.44 & 0.00 & 19.91 & 0.00 & 56.53 & 0.00 \\
\hline Concentration $\times$ Media & 10 & 1.38 & 0.19 & 6.92 & 0.00 & 2.48 & 0.00 & 7.68 & 0.00 \\
\hline Auxin $\times$ Concentration $\times$ & 20 & 0.99 & 0.46 & 4.29 & 0.00 & 7.34 & 0.00 & 19.83 & 0.00 \\
\hline
\end{tabular}

within a short period, for plantation programs at mass level.

\section{Materials and methods}

\section{Selection of planting material}

The study was carried out at the Arid Forest Research Institute, Jodhpur, Rajasthan, India $\left(24^{\circ} 40^{\prime} \mathrm{N}, 71^{\circ} 15^{\prime} \mathrm{E}\right)$ during JulySeptember (Monsoon season) of 2011. The climate of this region is hot and semi-arid, but influenced by monsoons.

\section{Preparation of stem cuttings}

The selection of Candidate Plus Tree (CPT) was done based on vegetative characters (i.e., growth potential; diameter at breast height; plant height; stem form; crown projection) and reproductive characters (i.e., regeneration ability; initiation of leaf fall; initiation of new leaves; initiation of flowering; number of flowers; initiation of fruiting; number of fruits/bunch; fruiting period), and

seed traits (100 seeds weight, g; oil percentage; seed viability; Azadirachtin percentage). The mini-cuttings were collected from selected CPT naturally growing at the Forest Genetics and Tree Breeding experimental field, in Jodhpur. The mini-stumps were propagated by conventional cutting methods (Stape et al. 2001, Schwambach et al. 2008, Wendling et al. 2010) from trees 30 months old. The newly emerging juvenile apical shoots (mini-cuttings) were harvested using sterile pruning scissors in the morning. After harvesting, these were first screened for the desired length $(30-35 \mathrm{~cm})$ and diameter $(<0.5 \mathrm{~cm})$ by scale and calibrated Vernier caliper. Then, they were kept in wet cloth (for prevention from damage) for transportation to the laboratory.

The mini-cuttings were defoliated and then treated with aqueous solution of $0.1 \%$ Carbendazim (Bavistin 50\% WP, Systemic fungicide, BASF India Limited, Bombay) for 1 minute, and subsequently washed with dis-
Tab. 2 - Mean values of the parameters analyzed (rooting percentage, number of root, root length in $\mathrm{cm}$, and number of leave) in mini cuttings of A.indica supplied with three different auxins and grown on different rooting media.

\begin{tabular}{llcccc}
\hline Parameter & Treatment & Sand & Vermiculite & Soil & Grand Mean \\
\hline Rooting \% & Control & 29.73 & 38.95 & 26 & 31.56 \\
& IBA & 59.07 & 54.44 & 30.78 & 48.09 \\
& IAA & 46.07 & 40.39 & 29.2 & 38.55 \\
& NAA & 37.85 & 37.94 & 20.24 & 32.01 \\
& Grand Mean & 46.72 & 44.15 & 26.73 & - \\
\hline Number & Control & 8 & 7.5 & 5 & 6.83 \\
of root & IBA & 76.24 & 53.05 & 33.81 & 54.36 \\
& IAA & 26.67 & 21.82 & 12.31 & 20.26 \\
& NAA & 53.13 & 43.91 & 12.89 & 36.94 \\
& Grand Mean & 53.31 & 42.98 & 20.37 & - \\
\hline Root length & Control & 2.6 & 2 & 2 & 2.2 \\
(cm) & IBA & 8.94 & 7.9 & 5.09 & 7.31 \\
& IAA & 8.83 & 6.8 & 5.17 & 6.93 \\
& NAA & 9.13 & 6.66 & 4.67 & 6.82 \\
& Grand Mean & 8.79 & 7.06 & 4.88 & - \\
\hline Numbers & Control & 3.4 & 2.75 & 2.5 & 2.88 \\
of leaves & IBA & 9.19 & 6.2 & 3.66 & 6.35 \\
& IAA & 4.07 & 3.25 & 2.72 & 3.34 \\
& NAA & 5.54 & 3.95 & 3.11 & 4.2 \\
& Grand Mean & 6.54 & 4.76 & 3.16 & - \\
\hline
\end{tabular}

tilled water to remove the excess of fungicide. The selected cuttings were treated with freshly prepared aqueous solution of root promoting auxins as described by Kroin (1992, 2011a, 2011b). The cuttings dipped in distilled water were considered as control or treated with IBA (Indole-3-Butyric Acid, Duchefa Biochemi, Postbus, Netherland), IAA (Indole-3-Acetic Acid, Duchefa Biochemi, Postbus, Netherland) and NAA ( $\alpha$ naphthalene acetic acid, Duchefa Biochemi, Postbus, Netherland), at different concentration of $100,250,500,750,1000$ and 1500

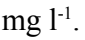

Twenty cuttings of each treatment were stuck in root trainer $(250 \mathrm{cc})$ containing three nursery grade rooting media: vermiculite, sand and soil.

The experiment was laid out in a Complete Randomized Block Design (CRBD). To prevent any form of damage to the cambium of cuttings during insertion into rooting medium, holes were made by a glass rod into the root trainer. The cuttings were kept under intermittent mist (misting flow for 60 seconds every 30 minutes), maintained at $60-80 \%$ relative humidity and $25-30{ }^{\circ} \mathrm{C} / 15$ $20{ }^{\circ} \mathrm{C}$ day/night temperature. The cuttings were regularly watered and treated with $0.1 \%$ Bavistin to avoid desiccation damage and attack of pathogens respectively, at 15day interval.

The rooting experiments were run for 60 days, then rooted cuttings were transferred to polythene bags $(16 \times 28 \mathrm{~cm})$ containing soil: FYM (field yard manure) $(5: 1)$ and kept in poly house for 15 to 20 days. The polythene bags were moved daily in order to minimize misting variation. After this, polythene bags containing rooted mini-cutting were transferred to agro-shade house for hardening. In agro-shade house, plants were manually irrigated by tap water once a day. After 35-45 days of hardening, plants were planted in the field and were manually irrigated by tap water once a week.

\section{Analysis of rooting in mini-cuttings}

After completion of experiment, all the cuttings were uprooted carefully with the help of running water. The number of leaves were recorded just before uprooting of a treatment lot, whereas the rooting success, numbers of primary roots and length of roots $(\mathrm{cm})$ were recorded by observing all mini-cuttings of each replication.

\section{Data collection and statistical analyses}

The recorded data were analyzed by general linear models using the software package SPSS ${ }^{\circledR} 8.0$ (SPSS Inc., Chicago, Illinois, USA). Data were subjected to ANOVA. Data in percentage was subjected to arcsine $(\sqrt{X})$ transformation (Snedecor \& Cochran 1967 ) before statistical analysis. 
Fig. 1 - De novo adventitious root formation in mini-cutting of $A$. indica. (A, B, C, $\mathrm{D})$ : Adventitious root formation in mini-cutting; (E, F, G, $\mathrm{H})$ : high rate of rooting in mini-cuttings treated with IBA 250 ppm; (I): field plantation of plant produced from mini-cutting; (J): plant produced from mini-cuttings in poly bags under poly house conditions.
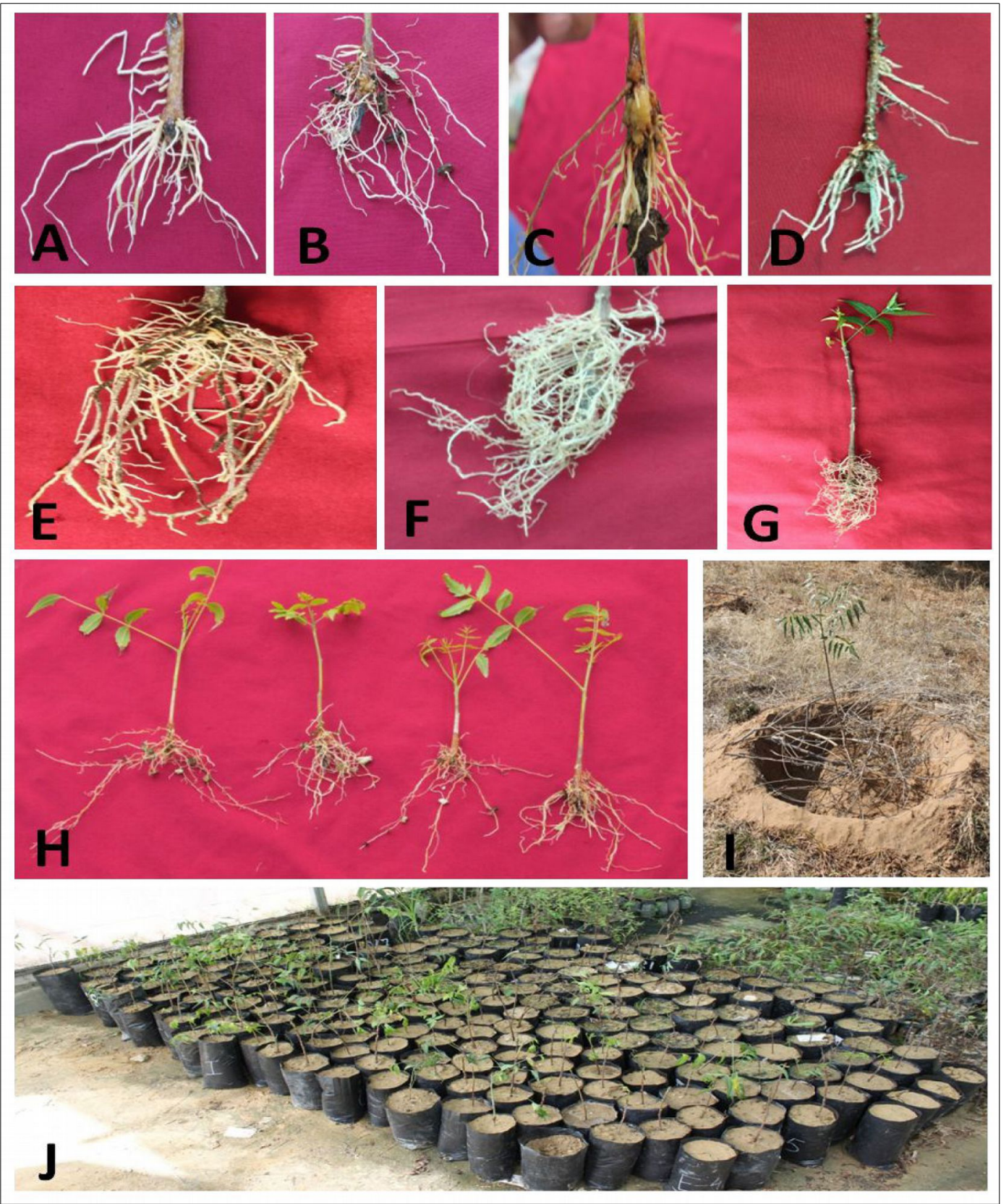

\section{Results and discussion}

A highly significant effect $(\mathrm{p}<0.001)$ of the three different rooting media on cuttings' performance was observed. The interaction of auxin, their concentration and rooting media had a significant effect $(\mathrm{p}<0.001)$ on the number of roots, root length and number of leaves (Tab. 1). The highest rooting percentage, numbers of roots, root length and numbers of leaves were $46.72 \%, 53.31,8.79$ and 6.54 , respectively, in sand rooting media, and lowest in soil rooting media with $26.73 \%, 20.37,4.88 \mathrm{~cm}$ and 3.16 , respectively (Tab. 2). The high root formation in sand could probably be attributed to a combination of water holding capacity and good aeration of the substrate. Indeed, aeration plays a significant role in root initiation as well as on root elongation (Khayyat et al. 2007). This could explain the observed low numbers of root and length in soil rooting media. In fact, the aeration in soil is usually low, while the water holding capacity is good.

El-Naggar \& El-Nasharty (2009) reported that rooting (pot size) and nutritional requirements are the most important factors affecting growth of ornamental plants. Khayyat et al. (2007) observed that the type of rooting media and their characteristics are of utmost importance for the quality of rooted cuttings, and attributed the improved root formation and growth of Epipremnum aureum cuttings to substrates containing mixtures of leaf mold and sand, due to the better aeration, drainage and water holding capa- city.

In this investigation, the highest number of leaves were formed in sand treatment, which can be attributed to the coordination between leaf and root development. According to Govinden-Soulange et al. (2009), the number of leaves produced per cutting is determined by the type of cutting used, plant growth regulators supplied and health status of the mother plant. Since all cuttings used in this investigation were uniform, the highest number of leaves per cutting observed for cuttings grown in sand could be attributed to intrinsic characteristics of stem cuttings, like root number and length.

A strong effect $(p<0.001)$ of all the three different auxins on the studied parameters was also observed. Results indicated that the 
Fig. 2 - Effect of IBA and rooting media (sand, vermiculite and soil) on rooting percentage, number of root, root length $(\mathrm{cm})$ and number of leaves in mini-cuttings of A.indica.

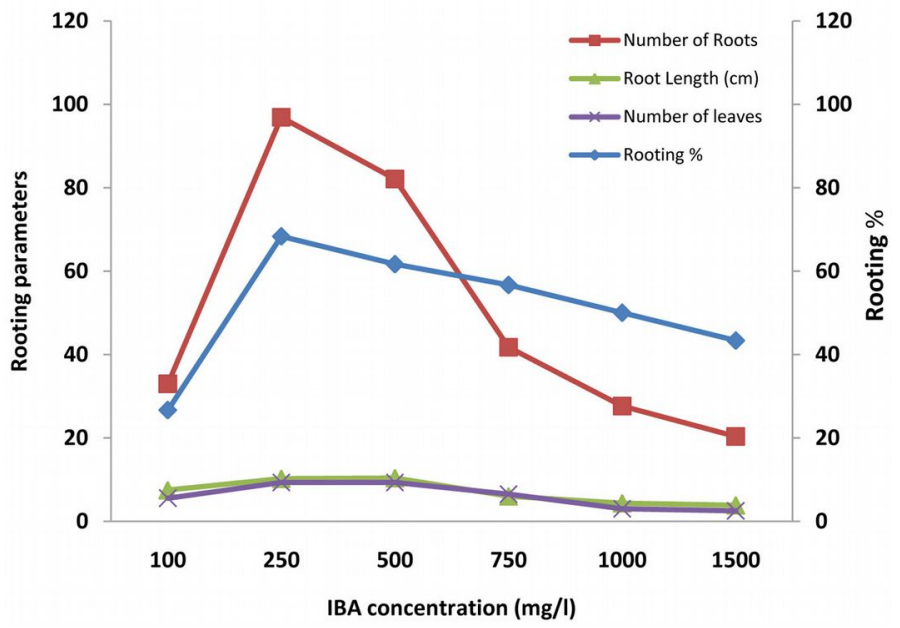

Fig. 3 - Effect of IAA and rooting media (sand, vermiculite and soil) on rooting percentage, number of root, root length $(\mathrm{cm})$ and number of leaves in

mini-cuttings of A.indica.

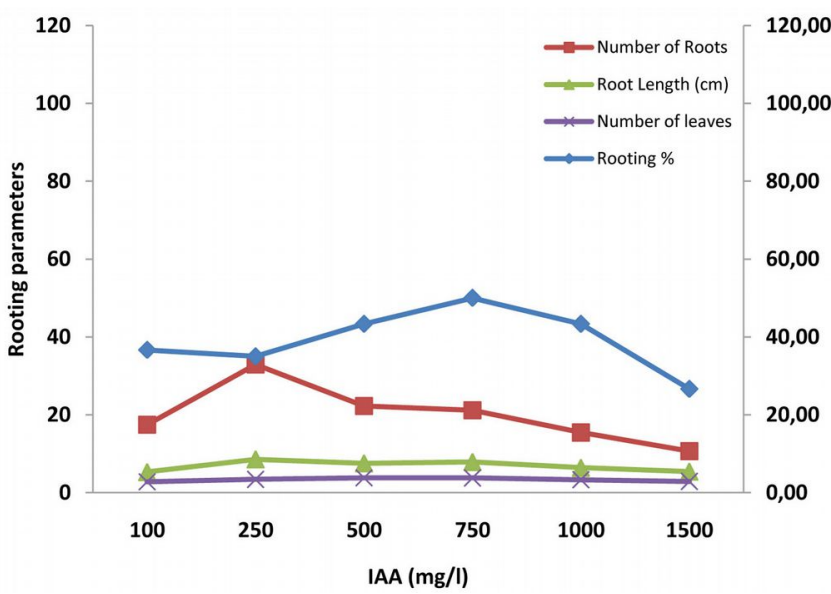

Fig. 4 - Effect of NAA and rooting media (sand, vermiculite and soil) on rooting percentage, number of root, root length $(\mathrm{cm})$ and number of leaves in mini-cuttings of A.indica.

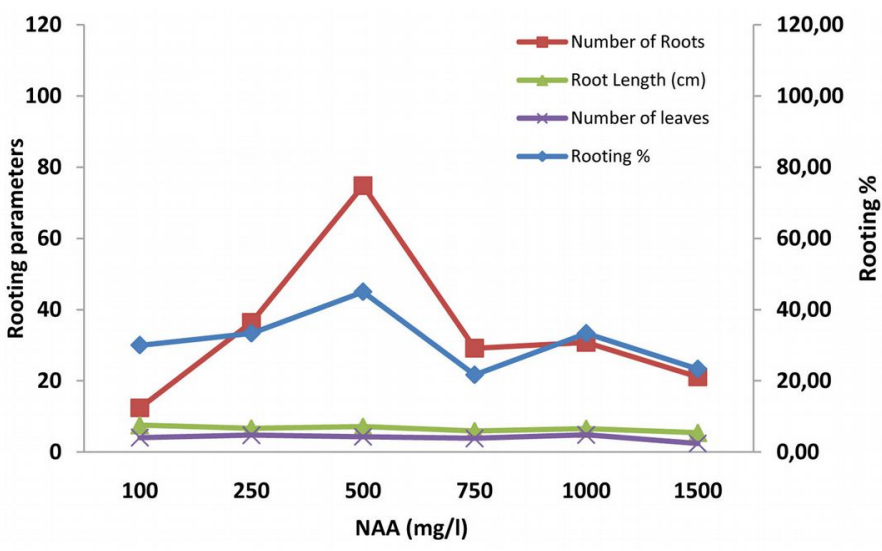

maximum rooting percentage, numbers of roots, root length and numbers of leaves were $48.09 \%, 54.36,7.3 \mathrm{~cm}$ and 6.35 , respectively, for the treatment with IBA; and the minimum values were $31.56 \%, 6.83$, $2.20 \mathrm{~cm}$ and 2.88 , respectively, in control (Tab. 2). Clearly, hormones of the auxin group promoted root formation. A higher percentage of rooting and number of roots per cutting were recorded with IBA than IAA $(38.55 \%$ and 26.94$)$ and NAA $(32.01 \%$ and 36.94 - Fig. 1). Gehlot et al. (2014) also found that the higher the rooting percent, the higher is the number of roots and length of roots in cuttings treated with IBA. This suggested that the use of IBA is more efficient than IAA and NAA in the present conditions (summer season).

The regeneration of adventitious root from softwood cuttings was also examined by Singh \& Chander (2001) who found higher rooting percentage and root numbers in cut- tings treated with IBA $(33.30 \%$ and 11.63$)$ followed by IAA (23.30\% and 6.67). Kesari et al. (2009) found relatively poor rooting with IAA treated stem cuttings of Pongamia pinnata in comparison to IBA. Tomar (1998) found that cuttings rooted effectively with IBA, and those from coppice shoots gave better results than cuttings from the main stem. The rooting capacity found in the present study indicates that the induction treatments imposed significantly enhanced the rooting ability of Azadirachta indica mini-cuttings, in the following order: IBA > IAA $>$ NAA (Fig. 2, Fig. 3, Fig. 4).

A significant relationship $(p<0.001)$ was also found between the rooting percentage and the concentration of auxins, in association with different rooting media. The overall rooting percentage varied greatly (Tab. $2)$. It was the highest $(90 \%)$ in treatment with $250 \mathrm{mg} \mathrm{l}^{-1} \mathrm{IBA}$ in sand rooting media, followed by $(80 \%) 500 \mathrm{mg} \mathrm{l}^{-1} \mathrm{IBA}$ in sand media; the lowest value was $10 \%$ (Tab. 3). Cuttings treated with $250 \mathrm{mg} \mathrm{l}^{-1}$ IBA in all the three potting media (sand, vermiculite and soil) gave the maximum success rate, in comparison with similar concentration of IAA and NAA; sand $(90 \%)>$ vermiculite $(80 \%)>$ soil $(35 \%)$. We hypothesize an interaction between physical properties of the rooting media and the effective auxin concentration (Fig. 2, Fig. 3, Fig. 4).

IBA was found more effective than IAA and NAA, in that order, in root induction in mini-cuttings of Neem and Commiphora wightii (Gehlot et al. 2014, Tripathi et al. 2014). Kesari et al. (2009) found relatively poor rooting with IAA treated stem cutting of Pongamia pinnata in comparison to IBA. Our study revealed that the rate of rooting success at various auxin concentrations increased until a threshold is reached, after which the rooting potential dropped, differentially for the auxins tested. In the case of IBA, the maximum success was reached with $250 \mathrm{mg} \mathrm{l}^{-1}(59.58 \%)$, in IAA with $750 \mathrm{mg} \mathrm{l}^{-1}$ $(47.20 \%)$ and in NAA with $500 \mathrm{mg} \mathrm{l}^{-1}$ (42.03\% - Tab. 3). Differences might be due to the auxin-specific toxic concentration (Grossmann 2000). Toxicity is followed by accelerated foliar senescence, chloroplast damage, destruction of membrane and vascular system integrity, necrosis and plant death. A high level of auxins stimulates biosynthesis of ethylene, which in turn triggers abscissic acid (ABA) production. The ABA is translocated through the plant, triggering stomatal closure and, together with ethylene, promotes leaf senescence and ultimately death (Grossmann 2000). Gehlot et al. (2014) also found different thresholds of auxin toxicity, in summer season, with values ranging from $57.46 \%$ (with IBA $500 \mathrm{mg}$ $\mathrm{1}^{-1}$ ), to $45.09 \%$ (with IAA $1000 \mathrm{mg} \mathrm{l}^{-1}$ ) and $49.31 \%$ (with NAA $750 \mathrm{mg} \mathrm{l}^{-1}$ ).

Statistically significant $(p<0.001)$ effect of 
Tab. 3 - Interactive effect of auxin (IBA, IAA \& NAA), their different concentration and rooting media (sand, vermiculite and soil) on root ing percentage and number of root in mini-cuttings of A.indica. $(*)$ : Arcsine values in parentheses.

\begin{tabular}{|c|c|c|c|c|c|c|c|c|c|}
\hline \multirow[t]{2}{*}{ Treatment } & \multirow{2}{*}{$\begin{array}{l}\text { Conc. } \\
\left(\mathrm{mg} \mathrm{l}^{-1}\right)\end{array}$} & \multicolumn{3}{|c|}{$\begin{array}{c}\text { Rooting percentage } \\
(\%)\end{array}$} & \multirow{2}{*}{ Mean } & \multicolumn{3}{|c|}{$\begin{array}{c}\text { Number of root } \\
(\text { Mean } \pm \text { SE) }\end{array}$} & \multirow{2}{*}{ Mean } \\
\hline & & Sand & Vermiculite & Soil & & Sand & Vermiculite & Soil & \\
\hline Control & 0 & $25(29.73)^{*}$ & $40(38.95)^{*}$ & $20(26.56)^{*}$ & $28.33(31.74)$ & $8.00 \pm 1.22$ & $7.50 \pm 0.57$ & $5.00 \pm 0.57$ & 6.83 \\
\hline \multirow[t]{6}{*}{ IBA } & 100 & $30(32.90)$ & $30(32.90)$ & $20(26.56)$ & $26.66(30.79)$ & $36.67 \pm 1.67$ & $36.00 \pm 0.82$ & $26.25 \pm 2.39$ & 32.97 \\
\hline & 250 & $90(76.08)$ & $80(66.59)$ & $35(36.06)$ & $68.33(59.58)$ & $149.56 \pm 10.76$ & $95.45 \pm 3.12$ & $45.71 \pm 1.30$ & 96.91 \\
\hline & 500 & $80(69.75)$ & $70(60.54)$ & 35 (36.06) & $61.66(55.45)$ & $105.69 \pm 17.00$ & $93.64 \pm 1.52$ & $47.00 \pm 6.62$ & 82.11 \\
\hline & 750 & $70(63.98)$ & 70 (63.98) & $30(32.90)$ & $56.66(53.62)$ & $51.86 \pm 1.77$ & $40.00 \pm 1.34$ & $33.33 \pm 2.11$ & 41.73 \\
\hline & 1000 & $70(63.98)$ & $60(57.64)$ & $20(26.56)$ & $50.00(49.39)$ & $32.14 \pm 1.79$ & $30.83 \pm 0.56$ & $20.00 \pm 5.77$ & 27.66 \\
\hline & 1500 & $60(54.49)$ & $50(45)$ & $20(26.56)$ & $43.33(42.02)$ & $26.67 \pm 0.71$ & $22.40 \pm 2.24$ & $12.00 \pm 0.98$ & 20.36 \\
\hline \multirow[t]{6}{*}{ IAA } & 100 & $50(45)$ & $30(29.46)$ & $30(32.90)$ & $36.66(35.79)$ & $24.00 \pm 0.67$ & $18.33 \pm 1.05$ & $10.00 \pm 0.90$ & 17.44 \\
\hline & 250 & $40(38.95)$ & 40 (38.95) & 25 (29.73) & $35.00(35.88)$ & $42.50 \pm 0.94$ & $31.25 \pm 0.82$ & $25.00 \pm 0.85$ & 32.92 \\
\hline & 500 & $60(51.34)$ & $50(45)$ & $20(26.56)$ & 43.33 (40.97) & $30.83 \pm 1.35$ & $26.00 \pm 1.25$ & $10.00 \pm 0.76$ & 22.28 \\
\hline & 750 & $70(63.98)$ & $60(51.05)$ & $20(26.56)$ & $50.00(47.20)$ & $27.86 \pm 0.69$ & $26.67 \pm 0.71$ & $9.00 \pm 0.58$ & 21.18 \\
\hline & 1000 & $50(45)$ & $50(45)$ & $30(32.90)$ & 43.33 (40.97) & $18.00 \pm 0.82$ & $17.00 \pm 0.82$ & $11.33 \pm 0.42$ & 15.44 \\
\hline & 1500 & $30(32.90)$ & $30(32.90)$ & $20(26.56)$ & $26.66(30.79)$ & $13.33 \pm 1.05$ & $11.67 \pm 1.05$ & $7.00 \pm 0.58$ & 10.67 \\
\hline \multirow[t]{6}{*}{ NAA } & 100 & $50(45)$ & $30(32.90)$ & $10(13.92)$ & $30.00(30.61)$ & $18.00 \pm 0.82$ & $13.33 \pm 1.05$ & $6.00 \pm 0.98$ & 12.44 \\
\hline & 250 & $40(38.95)$ & 40 (38.95) & $20(26.56)$ & $33.33(34.82)$ & $37.50 \pm 2.11$ & $61.71 \pm 3.24$ & $10.00 \pm 0.57$ & 36.40 \\
\hline & 500 & $60(51.34)$ & 55 (48.17) & $20(26.56)$ & $45.00(42.02)$ & $115.00 \pm 7.49$ & $89.50 \pm 9.94$ & $20.00 \pm 0.57$ & 74.83 \\
\hline & 750 & $10(13.92)$ & $45(41.83)$ & $10(13.92)$ & $21.66(23.22)$ & $30.00 \pm 1.07$ & $37.50 \pm 2.11$ & $20.00 \pm 0.37$ & 29.17 \\
\hline & 1000 & $50(45)$ & $40(39.23)$ & $10(13.92)$ & $33.33(32.72)$ & $46.00 \pm 4.99$ & $36.43 \pm 1.92$ & $10.00 \pm 0.57$ & 30.81 \\
\hline & 1500 & $30(32.90)$ & $20(26.56)$ & $20(26.56)$ & $23.33(28.67)$ & $28.33 \pm 1.05$ & $25.00 \pm 0.92$ & $10.00 \pm 0.57$ & 21.11 \\
\hline Total Mean & - & $50.79(46.72)$ & $47.11(44.15)$ & $21.84(26.73)$ & - & 53.31 & 42.98 & 20.37 & - \\
\hline
\end{tabular}

different doses of auxins and rooting media on the number and length of roots were observed. Overall the number and length of roots ranged from 5.00 and $2.60 \mathrm{~cm}$ (lower in control with soil and control with vermiculite) to 149 and $14.83 \mathrm{~cm}$ (highest in 250 $\mathrm{mg} \mathrm{l}^{-1}$ of IBA with sand), respectively (Tab. 3 Tab. 4). It is important to consider that growth regulators not only influence the percentage of rooting, rather they may also accelerate the onset of the rooting process and increase the number and quality (in terms of length) of roots. The maximum number of roots was recorded in the treatment with 250 $\mathrm{mg}^{-1}$ of IBA in all the rooting media. The control treatment resulted in thin roots, rather than in the inhibition of rooting, which indicates that endogenous auxin along with some root inducing factors might occur naturally within the mini cuttings that may boost root primordia initiation. Differences in the threshold of toxicity among the stu- died auxins was also an indication for specific endogenous levels (Blythe et al. 2007). The proper type and concentration of auxins in association with a proper rooting media is necessary to maximize the success of this propagation approach (Shagoo et al. 2007).

In most tree species, the rooting ability of cuttings has been reported to increase from the apical to the basal portion of the shoot, which has been attributed to accumulation of carbohydrates (Hartmann et al. 2011). In our

Tab. 4 - Interactive effect of auxin (IBA, IAA and NAA), their different concentration and rooting media (sand, vermiculite and soil) on root length $(\mathrm{cm})$ and number of leaves in mini-cuttings of A.indica.

\begin{tabular}{|c|c|c|c|c|c|c|c|c|c|}
\hline \multirow[t]{2}{*}{ Treatment } & \multirow{2}{*}{$\begin{array}{l}\text { Conc. } \\
\left(\mathrm{mg} \mathrm{l}^{-1}\right)\end{array}$} & \multicolumn{3}{|c|}{$\begin{array}{c}\text { Root Length } \\
(\text { Mean } \pm \text { SE, cm) }\end{array}$} & \multirow[t]{2}{*}{ Mean } & \multicolumn{3}{|c|}{$\begin{array}{l}\text { Number of leaves } \\
\text { (Mean } \pm \text { SE) }\end{array}$} & \multirow[t]{2}{*}{ Mean } \\
\hline & & Sand & Vermiculite & Soil & & Sand & Vermiculite & Soil & \\
\hline Control & 0 & $2.60 \pm 0.24$ & $2.00 \pm 0.38$ & $2.00 \pm 0.11$ & 2.20 & $3.40 \pm 0.40$ & $2.75 \pm 0.31$ & $2.50 \pm 0.29$ & 2.88 \\
\hline \multirow[t]{6}{*}{ IBA } & 100 & $8.00 \pm 0.26$ & $7.50 \pm 0.50$ & $7.00 \pm 0.41$ & 7.50 & $6.00 \pm 0.26$ & $5.00 \pm 0.45$ & $5.75 \pm 0.25$ & 5.58 \\
\hline & 250 & $14.83 \pm 1.11$ & $12.94 \pm 1.10$ & $3.00 \pm 0.25$ & 10.25 & $12.78 \pm 0.57$ & $11.29 \pm 0.66$ & $4.00 \pm 0.38$ & 9.35 \\
\hline & 500 & $11.25 \pm 1.20$ & $10.00 \pm 0.21$ & $10.00 \pm 0.44$ & 10.41 & $13.19 \pm 0.43$ & $9.75 \pm 0.19$ & $5.14 \pm 0.55$ & 9.36 \\
\hline & 750 & $6.57 \pm 0.14$ & $8.50 \pm 0.33$ & $3.00 \pm 0.32$ & 6.02 & $11.71 \pm 0.49$ & $5.50 \pm 0.19$ & $2.33 \pm 0.21$ & 6.51 \\
\hline & 1000 & $5.43 \pm 0.14$ & $4.67 \pm 0.14$ & $3.00 \pm 0.41$ & 4.36 & $4.43 \pm 0.14$ & $2.67 \pm 0.14$ & $2.00 \pm 0.14$ & 3.03 \\
\hline & 1500 & $4.33 \pm 0.14$ & $3.80 \pm 0.13$ & $3.50 \pm 0.29$ & 3.87 & $2.67 \pm 0.14$ & $3.00 \pm 0.21$ & $2.00 \pm 0.11$ & 2.55 \\
\hline \multirow[t]{6}{*}{ IAA } & 100 & $6.60 \pm 0.16$ & $5.00 \pm 0.48$ & $4.33 \pm 0.21$ & 5.31 & $3.00 \pm 0.11$ & $3.00 \pm 0.23$ & $2.33 \pm 0.21$ & 2.77 \\
\hline & 250 & $11.25 \pm 0.82$ & $8.50 \pm 0.33$ & $6.00 \pm 0.75$ & 8.58 & $4.50 \pm 0.33$ & $2.75 \pm 0.16$ & $3.00 \pm 0.21$ & 3.41 \\
\hline & 500 & $9.83 \pm 0.82$ & $6.80 \pm 0.25$ & $6.00 \pm 0.69$ & 7.54 & $5.17 \pm 0.11$ & $3.20 \pm 0.39$ & $3.00 \pm 0.37$ & 3.79 \\
\hline & 750 & $10.00 \pm 0.30$ & $8.67 \pm 0.28$ & $5.00 \pm 0.56$ & 7.89 & $4.00 \pm 0.33$ & $4.33 \pm 0.14$ & $3.00 \pm 0.45$ & 3.77 \\
\hline & 1000 & $7.40 \pm 0.27$ & $5.50 \pm 0.33$ & $6.33 \pm 0.21$ & 6.41 & $3.80 \pm 0.13$ & $3.20 \pm 0.13$ & $3.00 \pm 0.37$ & 3.33 \\
\hline & 1500 & $7.00 \pm 0.37$ & $6.33 \pm 0.21$ & $3.00 \pm 0.34$ & 5.44 & $3.67 \pm 0.21$ & $3.00 \pm 0.33$ & $2.00 \pm 0.11$ & 2.89 \\
\hline \multirow[t]{6}{*}{ NAA } & 100 & $15.20 \pm 0.13$ & $4.57 \pm 0.14$ & $3.00 \pm 0.41$ & 7.59 & $6.00 \pm 0.21$ & $4.27 \pm 0.14$ & $2.00 \pm 0.21$ & 4.09 \\
\hline & 250 & $5.50 \pm 0.33$ & $8.57 \pm 0.98$ & $6.00 \pm 0.54$ & 6.69 & $4.75 \pm 0.16$ & $5.00 \pm 0.67$ & $4.50 \pm 0.29$ & 4.75 \\
\hline & 500 & $7.67 \pm 0.41$ & $8.80 \pm 0.33$ & $5.00 \pm 0.48$ & 7.15 & $5.17 \pm 0.11$ & $4.75 \pm 0.16$ & $3.00 \pm 0.37$ & 4.30 \\
\hline & 750 & $5.00 \pm 0.21$ & $6.82 \pm 0.23$ & $6.00 \pm 0.37$ & 5.94 & $3.00 \pm 0.00$ & $3.55 \pm 0.21$ & $5.00 \pm 0.67$ & 3.85 \\
\hline & 1000 & $9.60 \pm 0.16$ & $5.18 \pm 0.18$ & $5.00 \pm 0.32$ & 6.59 & $8.40 \pm 0.58$ & $3.14 \pm 0.27$ & $3.00 \pm 0.35$ & 4.84 \\
\hline & 1500 & $7.33 \pm 0.84$ & $6.00 \pm 0.21$ & $3.00 \pm 0.21$ & 5.44 & $2.67 \pm 0.21$ & $3.00 \pm 0.68$ & $1.50 \pm 0.29$ & 2.39 \\
\hline Total Mean & - & 8.79 & 7.06 & 4.88 & - & 6.54 & 4.76 & 3.16 & - \\
\hline
\end{tabular}


case, the number of leaves was significantly $(p<0.001)$ affected by rooting media and concentration. The maximum number of leaves was observed in $500 \mathrm{mg} \mathrm{l}^{-1}$ IBA in association with sand (13.19), and the minimum (2.00) in soil with low or high concentrations of auxin (Tab. 3, Tab. 4). Cuttings treated with IBA in all the media exhibited a significant enhancement in the number of leaves compared to other auxins (Gehlot et al. 2014). The similarity in terms of rooting percentage, number and length of roots and numbers of leaves (Fig. 2, Fig. 3, Fig. 4) suggests that there was a physiological correlation between roots and the shoot, and opens new ground for studying vegetative propagation performance in neem.

\section{Conclusion}

In conclusion, sand was found to be superior in the propagation of Azadirachta indica cuttings when compared to the other media, for most of the root parameters determined. In mass propagation of Azadirachta indica for agroforestry purposes there is a need to maximize effective rooting, which may be obtained using mini-cuttings. Vegetative propagation through mini-cuttings was found to be a very promising method, which may replace the existing stem cuttings. The rooting media and plant growth regulator play a key role in this process. The formation of healthy plants after hardening in outdoor conditions further showed that Azadirachta indica could be successfully propagated by using mini cutting techniques. This new method of propagation provided the extension of propagation season (exploiting the months free of monsoon), higher yields of rooted cuttings per stock plant (using minicuttings) and a high rooting percentage (through rooting hormones).

\section{Acknowledgements}

Authors are thankful to the Director of AFRI, Jodhpur, Rajasthan, India for providing necessary facilities in the course of work. AG is also grateful to Department of Science and Technology, Rajasthan, India sanctioned student project for the year 20122013, and to Gilvano Ebling Brondani, Federal University of Mato Grosso / UFMT, Cuiabá - MT, Brazil for his valuable suggestions on an earlier version of the manuscript.

\section{References}

Almeida FD, Xavier A, Dias JMM, Paiva HN (2007). Auxin (IBA and NAA) effects on minicuttings rooting of Eucalyptus cloeziana F. Muell. clones. Revista Árvore 31 (3): 455-463. [in Portuguese] - doi: 10.1590/S0100-676220 07000300011

Brondani GE, Wendling I, Araujo MA, Pires PP (2008). Indol butyric acid in gel for minicuttings rooting of Eucalyptus benthamii Maiden and Cambage $\times$ Eucalyptus dunnii Maiden. Scientia
Agraria 9 (2): 153-158

Brondani GE, Wendling I, Grossi F, Dutra LF, Araujo MA (2010a). Eucalyptus benthamii $\times$ Eucalyptus dunnii minicutting technique: (ii) minicutting survival and rooting in relation to collection and seasons. Ciência Florestal 20 (3): 453-465.

Brondani GE, Grossi F, Wendling I, Dutra LF, Araujo MA (2010b). IBA application for rooting of Eucalyptus benthamii Maiden and Cambage $\times$ Eucalyptus dunnii Maiden minicuttings. Acta Scientiarum, Agronomy 32 (4): 667-674. - doi: 10.4025/actasciagron.v32i4.4879

Blythe EK, Sibley JL, Tilt KM, Ruter JM (2007). Methods of auxin application in cutting propagation: a review of 70 years of scientific discovery and commercial practice. Part-1. Journal of Environmental Horticulture 25 (3): 166-185. [online] URL: http://www.nurserycropscience.info/ propagation/timing-of-cutting-collection/technical-pubs/blythe-rooting-hormone-review-jeh-253-166-185.pdf

El-Naggar AH, El-Nasharty AB (2009). Effects of growing media and mineral fertilisation on growth, flowering, bulb productivity and chemical constituents of Hippeastrum vittatum, Herb. American-Eurasian Journal of Agriculture and Environmental Sciences 6 (3): 360-371. [online] URL: http://www.idosi.org/aejaes/jaes6(3)/17.pd f

Gehlot A, Gupta RK, Tripathi A, Arya ID, Arya S (2014). Vegetative propagation of Azadirachta indica: effect of auxin and rooting media on adventitious root induction in mini-cuttings. Advance in Forestry Science 1 (1): 1-9. [online] URL: http://200.129.241.78/ojs/index.php/afor/ article/view/1357

Garner RJ, Chaudri SA (1976). The propagation of tropical fruit trees. Hort Rev No. 5, Comm Bureau of Hort and Plant Crops, FAO and Commonwealth Agricultural Bureau, East Malling, UK, pp. 581. [online] URL: http://www.cabdirect.org/abstracts/19776715836.html

Goel VL, Behl HM (2004). Variations and vegetative propagation of Azadhirachta indica. Journal of Tropical Medicinal Plants 5 (1): 119-125.

Govinden-Soulange JN, Boodia C, Dussooa R, Gunowa S, Deensah S, Facknath B (2009). Vegetative propagation and tissue culture regeneration of Hibiscus sabdariffa L. (Roselle). World Journal of Agricultural Sciences 5 (5): 651-661. [online] URL: http://www.idosi.org/wjas/wjas5 (5)/21.pdf

Grossmann K (2000). Mode of action of auxin herbicides: a new ending to a long, drawn out story. Trends in Plant Science 5 (12): 506-508. doi: 10.1016/S1360-1385(00)01791-X

Hartman HT, Kestler DE, Davies FT (1990). Plant propagation principles and practices $\left(5^{\text {th }}\right.$ edn). Prentice Hall, Englewood Cliff, NJ, USA, pp. 400.

Hartmann HT, Kester DE, Davies FTJ, Geneve RL (2011). Plant propagation: principles and practices $\left(8^{\text {th }}\right.$ edn). Prentice-Hall, New York, USA, pp. 915 .

Hartmann HT, Kester DE, Davies JFT, Geneve RL
(2007). Plant hormones. In: "Plant Propagation: Principle and Practices" ( $7^{\text {th }}$ edn). Prentice-Hall, New Delhi, India, pp. 292-320.

Heloir MC, Kevers C, Hausman JF, Gaspar T (1996). Changes in the concentrations of auxins and polyamines during rooting of in-vitro-propagated walnut shoots. Tree Physiology 16 (5): 515-519. - doi: 10.1093/treephys/16.5.515

Kesari V, Anitha K, Latha R (2009). Effect of auxins on adventitious rooting from stem cuttings of candidate plus tree Pongamia pinnata (L.), a potential biodiesel plant. Trees 23 (3): 597-604. - doi: 10.1007/s00468-008-0304-x

Khayyat M, Nazari F, Salehi H (2007). Effects of different pot mixtures on Pothos (Epipremnun aureum Lindl. \& Andre "Golden Pothos") growth and development. American-Eurasian Journal Agriculture and Environment Science 6 (3): 360-371.

Kroin J (1992). Advances using Indole-3-butyric acid (IBA) dissolved in water for rooting cuttings, transplanting and grafting. Combined Proceedings - International Plant Propagators Society 42: 489-492.

Kroin J (2011a). How to improve cutting propagation using water based indole-3-butyric acid rooting solutions. Combined Proceedings - International Plant Propagators Society 61: 381-391.

Kroin J (2011b). Hortus plant propagation from cuttings. A guide to using plant rooting hormones. Hortus, New York, USA, pp. 55.

Kundu SK, Luukkanen O (2003). Genetic diversity and breeding strategies of the Neem (Azadirachta indica). In: "XII World Forestry Congress". Quebec City (Canada) 21-28 September 2003, Paper no. 0601-B1. [online] URL: http://www.fao.org/docrep/ARTICLE/WFC/XII/ 0601-B1.HTM

Li SW, Xue L, Xu S, Feng H, An L (2009). Mediators, genes and signaling in adventitious rooting. The Botanical Review 75 (2): 230-247. doi: 10.1007/s12229-009-9029-9

Lovell PH, White J (1986). Anatomical changes during adventitious root formation. In: "New root formation in plants and cuttings" (Jackson MB ed). Martinus Nijhoff Pubs, Boston, MS, USA, pp. 111-140. - doi: 10.1007/978-94-0094358-2_4

Majada J, Martínez-Alonso C, Feito I, Kidelman A, Aranda I, Alía R (2011). Mini-cuttings: an effective technique for the propagation of Pinus pinaster Ait. New Forests 41 (3): 399-412. - doi: 10.1007/s11056-010-9232-X

Parthiban KT, Surendran C, Murugesh M, Buvaneswaran C (1999). Vegetative propagation of a few multipurpose tree species using stem cuttings. Advances in Horticulture and forestry 6: 175-178. [online] URL: http://www.crec.ifas.ufl.edu/extension/windbreaks/resources/PDF/Veg Prop_a_few_tree_species.pdf

Purohit SD, Dave A (1996). Micropropogation of Sterculia urens Roxb. - an endangered tree species. Plant Cell Reports 15 (9): 704-706. - doi: 10.1007/BF00231929

Schwambach J, Ruedell CM, Almeida MR, Penchel RM, Araújo EF, Fett-Neto A (2008). 
Adventitious rooting of Eucalyptus globulus $\times$ E. maidennii mini-cuttings derived from ministumps grown in sand bed and intermittent flooding trays: a comparative study. New Forests 36 (3): 261-271. - doi: 10.1007/s11056-0089099-2

Shagoo P, Beigh MA, Lone RA, Nanda AB (2007). Effect of plant growth regulators on rooting of Barbados cherry. Asian Journal of Horticultural 2 (1): 152-154. [online] URL: http:// www.cabdirect.org/abstracts/20083144681.html

Singh RR, Chander H (2001). Effect of auxins on rooting behaviour of neem (Azadirachta indica) branch cuttings. Indian Forester 127: 1019-1024.

[online] URL: http://www.indianforester.co.in index.php/indianforester/article/view/2976

Snedecor GW, Cochran WG (1967). Statistical methods. The Iowa State University Press, Iowa, USA, pp. 327-329.

Stape JL, Gonçalves JLM, Gonçalves AN (2001).

Relationships between nursery practices and field performance for Eucalyptus plantations in Brazil. New Forests 22 (1-2): 19-41. - doi: 10.10 23/A:1012271616115

Titon M, Xavier A, Otoni WC (2006). Clonal propagation of Eucalyptus grandis using the mini-cutting and microcutting techniques. Scientia Forestalis 71: 109-117.

Tomar UK (1998). Macro- and micropropagation of adult neem trees. In: Proceedings of the "Workshop on Neem" (Azadirachta indica). Arid Forest Research Institute, Jodhpur, India, pp. 8-9.

Tripathi A, Shukla JK, Gehlot A, Mishra DK (2014). Standarization of cloning in Commiphora wightii. Advance in Forestry Science 1 (1): 19-25. [online] URL: http://www.periodicoscientificos.ufmt.br/ojs/index.php/afor/article/vie w/1358

Wendling I, Brondani GE, Dutra LF, Hansel FA (2010). Mini-cuttings technique: a new ex vitro method for clonal propagation of sweetgum.
New Forests 39 (3): 343-353. - doi: 10.1007/s11 056-009-9175-2

Wendling I, Xavier A (2005). Indolbutiric acid and serial minicutting technique on rooting and vigor of Eucalyptus grandis clone mini cuttings. Revista Árvore 29 (6): 921-930. [in Portuguese] [online] URL: http://www.scielo.br/scielo.php? pid $=$ S0100-67622005000600011\&script $=$ sci_art text\&tlng=es

Wiesman Z, Riov J, Epstein E (1988). Comparison of movement and metabolism of indole-3acetic acid and indole-3-butyric acid in mung bean cuttings. Physiologia Plantarum 74 (3): 556-560. - doi: 10.1111/j.1399-3054.1988.tb020 $18 . \mathrm{x}$

Woodward AW, Bartel B (2005). The Arabidopsis peroxisomal targeting signal type 2 receptor PEX7 is necessary for peroxisome function and dependent on PEX5. Molecular Biology of the Cell 16: 573-583. - doi: 10.1091/mbc.E04-050422 